\section{The Darwin Initiative for the Survival of Species}

Last week a group of Brazilian and American scientists warned that a plan to build a network of roads and other communication links in Brazil was no less than a 'death sentence' for the rainforests of the region. Today, as I write, my newspaper carries a story suggesting that global warming attributable to human activities may be 'unstoppable'; on another page I read that oil leaking from the stricken tanker Jessica, now on the verge of break-up, is threatening to irrevocably damage the unique and fragile ecosystems of the Galapagos Islands. Stories such as these are so commonplace that one can all too easily assume that the destruction of the earth's biodiversity is inevitable and that there is little or nothing we can do about it. However, as Tam Dalyell MP said when the Red Data Book for plants was published: 'We should not simply wring our hands. It is a public issue. It is also a window of opportunity'.

The first Earth Summit in Rio de Janeiro, almost 10 years ago now, placed facts about the erosion of biodiversity firmly onto the political agenda of almost every country in the world, not least that of the United Kingdom (UK). At Rio, the then Prime Minister, John Major MP, announced The Darwin Initiative for the Survival of Species. What at first seemed little more than King Canute's attempts to turn back the ocean's tides has in fact become a very remarkable contribution to the fight against the catastrophic destruction of the earth's biodiversity. A sum of $£ 6$ million over 3 years was to be made available to support a programme 'to draw on UK scientific, educational and commercial strengths to assist in conserving the world's biodiversity and natural habitats, by helping those countries rich in biodiversity but poor in resources to implement their obligations under the UN Convention on Biological Diversity'.

The emphasis in allocating this money was to be on working in partnership, pairing UK and local expertise, with biodiversity and its sustainable use being seen in the context of wider economic, agricultural and social agendas. Leaving behind a lasting legacy was to be an essential prerequisite for the acceptance of projects for funding. The Fund grew to $£ 3$ million annually, and since 1997 the Initiative has been embraced by the Labour Government, being placed under the care of the Minister for the Environment, Michael Meacher MP. He has given it tremendous support. A sum of $£ 24$ million have so far been allocated and I have every hope that before long the Fund will grow even further.

The Advisory Committee to the Initiative, first chaired by Sir Crispin Tickell and now by me, has recommended support for over 200 projects in more than 80 different countries. In the year 2000 alone, funded projects included the conservation of orang-utans in Sabah, studies of tree diversity in Peru and of plankton diversity in the seas off the Seychelles and Mauritius, big cat conservation in South Africa, the conservation and rehabilitation of Colombian rainforests by indigenous peoples, and biodiversity training and capacity building in Poland -20 projects in total carried out by UK research institutes, museums, botanic gardens, universities and NGOs, working in concert with scientists, conservationists, educators, politicians and business people in the partner countries. The impact has been immense. Our monitoring shows that the lasting legacy has been very significant and, most important of all, the Initiative and its way of working has become a model for the support of international efforts in conservation and sustainable use that others are keen to copy. We shall be taking that model to Rio+10 in 2002, where we hope that others will see its importance as a way of working.

So, a small sum of money, relative to the size of the problem to be tackled, has had a far-reaching impact because:

- it achieves great leverage by marrying UK expertise with local knowledge;

- projects attract matching funds, and often expertise, from other sources;

- programmes are carefully designed to leave a lasting legacy;

- education and training are major components in almost every case.

But don't think that the Darwin Initiative is resting on its laurels. We know that we can be even more effective in the future, and hence new members have been added to the Advisory Committee, complementary in their expertise and all very active in the struggle to conserve biodiversity and ensure its sustainable use. Their thoughts and ideas are being added to those of the existing Advisory Committee to help us plan for an exciting future. Also, we have commissioned the Edinburgh Centre for Tropical Forests (ECTF) to monitor and 
evaluate our work over the next 2 years and provide us with the constructive criticism we need to keep us on our toes. Finally, we have invited everyone working towards the conservation and sustainable use of biodiversity to give us their views about what we do and how we do it.

If you would like to know more about the Darwin Initiative for the Survival of Species, why not visit our developing web-site at www.nbu.ac.uk/darwin. If you would like to give us your views about the Initiative and its future plans, tell us by e-mail (sarah_collins@detr.gsi.gov.uk) or by writing to me at the Darwin Initiative, Department of the Environment, Transport and the Regions, Zone 4/A1, Ashdown House, 123 Victoria Street, London SW1E 6DE, UK. Finally, if you would like to submit an application for an award, please write to the above address asking for an information pack. We are currently considering this year's round of applications, but the deadline for the submission of new projects, autumn 2001, is not far away. We look forward to hearing from you.

Professor David Ingram

Chairman, Advisory Committee to the

Darwin Initiative for the Survival of Species 